\title{
Class Is Not Dead - It Has Been Buried Alive Class Voting and Cultural Voting in Postwar Western Societies (1956- 1990) ${ }^{1}$
}

\author{
Jeroen van der Waal \\ Peter Achterberg \\ Dick Houtman \\ Running head \\ Class Is Not Dead \\ Address of correspondence \\ Jeroen van der Waal \\ Department of Sociology \\ Faculty of Social Sciences \\ Erasmus University \\ P.O. Box 1738 \\ 3000 DR Rotterdam \\ The Netherlands \\ Telephone \\ $+31-10-4088668 / 2085$ \\ Fax \\ $+31-10-4089098$ \\ Email \\ vanderwaal@fsw.eur.nl
}

\footnotetext{
${ }^{1}$ This paper is based on Jeroen van der Waal's MA thesis, which has been supervised by Peter Achterberg and Dick Houtman. The authors are affiliated with the Department of Sociology of Erasmus University, Rotterdam, the Netherlands - Jeroen van der Waal as a Ph.D. student, Peter Achterberg as a postdoc, and Dick Houtman as an associate professor of sociology.
} 


\begin{abstract}
$\underline{\text { Abstract }}$
By means of a re-analysis of the most relevant data source (Nieuwbeerta \& Ganzeboom 1996), this paper criticizes the newly grown consensus in political sociology that class voting has declined since World War II. An increase of crosscutting cultural voting, rooted in educational differences, rather than a decline of class voting proves responsible for the decline of the traditional class-party alignments. Moreover, income differences have not become less, but more consequential for voting behavior during this period. It is concluded that the new consensus has been built on quicksand. Class is not dead - it has been buried alive under the increasing weight of cultural voting, systematically misinterpreted as a decline of class voting, due to the widespread application of the Alford index.
\end{abstract}




\section{Class Is Not Dead - It Has Been Buried Alive}

\section{Class Voting and Cultural Voting in Postwar Western Societies (1956-1990)}

No one suspected (...) or had reason to suspect, that she was not actually dead. She presented all the ordinary appearances of death. The funeral (...) was hastened, on account of the rapid advance of what was supposed to be decomposition (Edgar Allan Poe, The Premature Burial, 1844).

\section{Introduction}

With their polemically titled article 'Are Social Classes Dying?' Clark and Lipset (1991) put the cat among the pigeons of class analysis by defending the thesis that the political relevance of class had declined substantially since World War II. Their article sparked a lively debate, yielding publications with titles such as The Death of Class (Pakulski \& Waters 1996), The Promising Future of Class Analysis (Goldthorpe \& Marshall 1992), and The Breakdown of Class Politics (Clark \& Lipset 2001, see Clark 2001 for a review). Although some initially rejected Clark and Lipset's claim (e.g. Evans 2000, Goldthorpe 2001, Hout et al. 1993, Manza et al. 1995), it has in the meantime become generally accepted that they were basically correct. "With respect to politics, social classes are certainly not dead, but the rumours of their imminent death are not all that exaggerated", as Nieuwbeerta (2001: 132) summarizes this new consensus (see also Brooks et al. 2004, Evans et al. 1996, Heath et al. 1999, Weakliem \& Heath 1999).

And yet, a remarkable set of research findings suggests that this consensus may be built on quicksand. Whereas Nieuwbeerta (1995, 1996, 2001, Nieuwbeerta and De Graaf 1999) has demonstrated that in the United States the relationship between class and voting has declined in the postwar era, political scientist Stonecash (2000), relying on a different class measure, has demonstrated that class voting has in fact become stronger during this period. Consistent with the latter's findings, the salience of class issues has not at all declined since World War II and the strength of the relationship between class and voting does not depend on the salience of class issues (Achterberg 2006). Perhaps most surprising, and again suggesting that something is seriously wrong, contextual hypotheses derived from the class approach to politics prove strikingly impotent in explaining the strength of the relationship between class and politics (Nieuwbeerta 1995, Nieuwbeerta \& Ultee 1999).

Taken together, those findings raise the question whether the erosion of the traditional alignment of the working class with the left and the middle class with the right since World War II has 
really been caused by a decline of class voting. In what follows, we therefore develop and test an alternative explanation.

\section{Class Voting and Cultural Voting: A Reconceptualization}

\subsection{Income and Education: Two of a Kind?}

The insight that the working class is liberal or progressive when it comes to issues of economic redistribution, but conservative or authoritarian when cultural issues of individual liberty and maintenance of social order are at stake, is one of the staples of political sociology (e.g. Lipset 1981, Middendorp 1991, Houtman 2001, Houtman 2003). In Lipset's classical formulation: "Economic liberalism refers to the conventional issues concerning redistribution of income, status, and power among the classes. The poorer everywhere are more liberal or leftist on such issues (...) On the other hand, when liberalism is defined in non-economic terms - so as to support, for example, civil rights for political dissidents, civil rights for ethnic and racial minorities, internationalist foreign policies, and liberal immigration legislation - the correlation is reversed" (Lipset 1959: 485). Since Lipset's pioneering work in this area it has become uncontested that economic and cultural liberalism are almost unrelated among the public at large (e.g. Fleishman 1988, Heath et al. 1994, Middendorp 1991).

When it comes to the explanation of economic liberalism, education and income can be considered aspects of the same class phenomenon, because a low level of education and a low income both lead to a preference of economic redistribution, thus confirming the logic of class analysis (De Witte \& Billiet 1999, Scheepers et al. 1999, Wright 1985, Achterberg \& Houtman 2006, Houtman 2001, Houtman 2003). When it comes to explaining non-economic types of political values, relating to the degree to which one emphasizes individual liberty - e.g., postmaterialism in the sense of Inglehart (1977) - or maintenance of social order - e.g., authoritarianism in the sense of Adorno et al. (1950) -, however, the picture is radically different. In this case, income does not have any explanatory power, whereas education strongly affects authoritarianism and postmaterialism (negatively and positively, respectively) (Houtman 2003). Inglehart (1977: 72-89) rightly concludes from this that education does not simply indicate class or occupational status (see also Houtman 2001, Houtman 2003). And indeed, it is by and large agreed today that working-class authoritarianism, unlike working-class economic progressiveness, has nothing to do with its weak economic position and everything with its limited level of education (e.g. Dekker \& Ester 1987, Grabb 1979, 1980, Van de Werfhorst \& De Graaf 2004).

Although sociologists have always underscored that social class (like socio-economic status, for that matter) is closely related to both education and income (e.g. Duncan 1961, Hout et al. 1993, 
Ishida \& Muller 1995, Kohn 1977, Lipset 1981, Marshall et al. 1988, Van de Werfhorst \& De Graaf 2004), in short, those research findings point out that education cannot be taken to indicate class just like that. It can when the explanation of economic liberalism is at stake, but it cannot when we are dealing with the explanation of cultural liberalism ("postmaterialism") or cultural conservatism (“authoritarianism") (Houtman 2001, Houtman 2003).

\subsection{Distinguishing Cultural Voting from Class Voting}

Notwithstanding their lack of explanatory power for authoritarianism, postmaterialism and the like, class and income are of course strongly and positively related to education. This circumstance makes it quite problematic that studies on class voting typically rely on an index introduced by Alford (1967) in the 1960s. This so-called "Alford index" measures the strength of the bivariate relationship between class and voting. The almost universal acceptance of this practice is underscored by the circumstance that it is not only used by Clark and Lipset in their influential article (1991), but also accepted by their critics, although the latter suggest some methodological refinements (Hout et al. 1993). Nieuwbeerta (1995, 1996, 2001, Nieuwbeerta and De Graaf 1999) also uses the Alford index in his large-scale study, which has been vital in establishing the contemporary consensus, just like a variety of researchers who have contributed chapters to the two key volumes about the Death of Class Debate (Clark \& Lipset 2001, Evans 1999).[1]

Under the heading Why Expect Class Voting?, Alford (1967) has argued that his approach is based on the assumption that class-related economic interests underlie the familiar relationship between class and voting: "A relation between class position and voting behavior is a natural and expected association in the Western democracies for a number of reasons: the existence of class interests, the representation of these interests by political parties, and the regular association of certain parties with certain interests. Given the character of the stratification order and the way political

parties act as representatives of different class interests, it would be remarkable if such a relation were not found" (1967: 68-69). Although Alford thus correctly underscores that the familiar alignments emerge from working-class economic liberalism and middle-class economic conservatism, his index nevertheless neglects this voting motivation and merely relies on the strength of the bivariate relationship between class position and voting behavior.

This omission is quite problematical, because Alford's index thus effectively mixes up class voting, i.e., voting for a leftist (rightist) party on the basis of economic liberalism (conservatism) that is rooted in a weak (strong) class position, with what we shall henceforth call cultural voting, i.e., voting for a rightist (leftist) party on the basis of authoritarianism (libertarianism) that is rooted in a low (high) level of education (Achterberg \& Houtman 2006, Houtman 2001, Houtman 2003). It needs to be underscored that the latter type of voting has nothing to do with the former, because it is driven 
by a cultural rather than an economic voting motivation, stems from education rather than class, and cross pressures the electorate to vote contradictory to its class-based economic interests.

[INSERT FIGURE 1: Class Voting Distinguished from Cultural Voting. ABOUT HERE]

Figure 1 disentangles both types of voting: the upper part denotes class voting and the lower part crosscutting cultural voting. It points out that the strength of the relationship between class and voting, as it is measured by the Alford index, cannot tell us anything about the degree to which class affects the vote. This is because both types of voting work in opposite directions and may vary independent of one another. A preference for economic redistribution that is rooted in a weak class position and that drives leftist voting, perfectly consistent with the logic of class voting, can thus be cancelled out by an equally strong tendency among the poorly educated to vote for rightist parties, driven by high levels of authoritarianism. Measuring class voting as the strength of the bivariate relationship between class and voting then leads to the mistaken conclusion that "class does not affect the vote". It is important to underscore that this is not merely a hypothetical construction, but rather a realistic image of what occurs in the real world (Achterberg \& Houtman 2006, Houtman 2001, Houtman 2003). Reliance on the bivariate relationship between class and voting can even produce the conclusion that "class voting has declined" if it has in fact increased. This happens if class voting and cultural voting have both increased, but the latter more so than the former.

\subsection{Hypotheses}

It is not clear at all, to sum up the foregoing, whether the decline of the familiar alignment of the working class with the left and the middle class with the right since World War II, convincingly documented by Nieuwbeerta (1995, 1996, 2001, Nieuwbeerta and De Graaf 1999), has really been caused by a decline of class voting. It is certainly possible that it has, but it may also have been caused by an increase of cultural voting. And indeed, as already briefly indicated above, three sets of research findings point in the direction of the latter possibility.

Firstly, Stonecash (2000: 140), relying on income for the measurement of class, has demonstrated that the relationship between class and voting has become stronger rather than weaker in the United States since World War II, concluding: "rather than class divisions fading in relevance, they are likely to be a staple of American politics for some time". Telling detail: Nieuwbeerta relies on the same data as Stonecash, although he adds data from other countries to those. The difference between their findings, then, seems particularly caused by Stonecash's decision to use income categories and Nieuwbeerta's to instead rely on the (occupation-based) EGP class schema (Erikson \& Goldthorpe 1992, Erikson et al. 1979). Our discussion above points out that this is not a trivial difference, because income categories, unlike occupational categories, are not susceptible to the 
problem of mixing up class voting and cultural voting, because no relationship exists between income and authoritarianism / libertarianism. With those two operationalizations of class producing such radically different findings, the decline of the traditional class-party alignments that Nieuwbeerta has demonstrated (1995, 1996, 2001, Nieuwbeerta and De Graaf 1999) therefore more likely denotes an increase of cultural voting than a decline of class voting.

Secondly, if a decline of class voting had taken place since World War II, we would expect that class issues would have become less politically salient during this period. This is not the case, however (Achterberg 2006), although it is equally clear that cultural issues of individual liberty and social order have become more salient during this period (Hechter 2004, Layman 2001, Achterberg 2006). Moreover, the salience of class issues does not affect the strength of the relationship between class and voting at all, whereas this relationship is substantially weaker in periods and countries in which cultural issues are more salient (Achterberg 2006). This suggests, again, that we have not been witnessing a decline of class voting, but rather an increase of cultural voting since World War II.

Thirdly, class analysis proves remarkably impotent in predicting the periods and countries in which the relationship between class and voting is weakest. Hypotheses derived from the class approach to politics, predicting the circumstances under which class distinctions are more or less salient, are rejected almost without exception (Nieuwbeerta 1995, Nieuwbeerta \& Ultee 1999). If differences in the bivariate relationship between class and voting are taken to indicate differences in levels of class voting, those findings are obviously very surprising. Although it is of course conceivable that the class approach to politics is completely flawed, we consider it at least equally likely that differences in the bivariate relationship between class and voting indicate differences in levels of cultural voting instead. If this is the case - and this is precisely what the two other clusters of findings that we have just discussed suggest -, the failure of hypotheses derived from the class approach to politics ceases to be surprising.

To find out whether the declining alignment of the working class with the left and the middle class with the right has been caused by a decline of class voting or by an increase of cultural voting, we re-analyze Nieuwbeerta's data. We test two hypotheses. The first one tests whether a decline of class voting has occurred. It predicts that the decline of the relationship between EGP class and voting behavior has been caused by a decline of the tendency of those with low incomes to vote for parties on the left and those with high incomes to vote for parties on the right. The second hypothesis tests whether an increase of cultural voting has taken place. It predicts that the decline of the relationship between EGP class and voting behavior has been caused by an increase of the tendency of the poorly educated to vote for parties on the right and the highly educated to vote for parties on the left.

\section{Data and Measurement}




\subsection{Data}

As mentioned above, we re-analyze the data Nieuwbeerta has used to demonstrate the decline of the traditional alignment of the working class with the left and the middle class with the right (Nieuwbeerta \& Ganzeboom 1996). Due to two deviations from Nieuwbeerta's measurement of voting behavior, to be discussed below, we analyze data about 93,567 respondents, who have been sampled in 15 different countries between 1956 and 1990, adding up to a total of 80 combinations of country and year (see Table 1).

[INSERT TABLE 1: Number of data files for each of the combinations of country and period (19561990, $\mathrm{N}=80$ ). ABOUT HERE]

\subsection{Measurement}

Class - Like Nieuwbeerta, we measure class by means of the EGP class schema, which assigns seven different class positions on the basis of occupation, self-employed status and number of people supervised (Erikson \& Goldthorpe 1992: 38-39). It is important to emphasize that the seven EGP classes do not constitute a simple hierarchy (Goldthorpe 1980: 42). The three nonmanual classes (higher professionals, lower professionals, and non-manual workers) and the three manual ones constitute two separate hierarchies, to be sure, but the hierarchical relationship between these two is undetermined. The same goes for the relationship between each of those hierarchies and the petty bourgeoisie. The higher professionals, the lower professionals, and the petty bourgeoisie can be classified unambiguously as middle class, while the classes of skilled manual workers on the one hand and semi-skilled and unskilled manual workers on the other together constitute the working class. The third and most privileged manual class constitutes "a latter-day aristocracy of labour or a 'blue collar' élite” (Goldthorpe 1980: 41). It consists of lower-grade technicians and supervisors of manual workers and can as such be distinguished from the "real" working class. Likewise, the least privileged nonmanual class, i.e., that of nonmanual workers, can be distinguished from the "real" middle class as consisting of "white collar proletarians" (e.g. Wright 1979). In interpreting the statistical results, in short, especially the voting behavior of the higher professionals, lower professionals, and petty bourgeoisie on the one hand ("middle class") and the

skilled, semi-skilled and unskilled manual workers on the other ("working class') is important. EGP class is entered into the analysis as a series of six dummy variables, using the higher professionals as the reference category.

$\underline{\text { Income }}$ - Following Erikson (1984), net household income is used to determine income levels. To allow comparison of the regression coefficients of income with other variables this variable has been standardized first for each country and year combination separately. 
Education - To standardize the educational classifications in the 15 countries, education has first been recoded into the number of years minimally required to attain the level of education at hand and has next been standardized in the same way as income.

Voting behavior - like Nieuwbeerta (1995: 35), we have used data about the party one would vote for if elections were held today (or soon), about the party one has voted for in the past, and the party one identifies with. If valid answers to all of these three questions were available, we used the first one, i.e., voting intention. If valid answers to only the last two were available, we used party identification. We do not use Nieuwbeerta's crude left versus non-left distinction, because it creates more or less arbitrary decisions in coding parties in the political center. We instead scale voting behavior according to left-right self-placement, so as to produce a continuous variable with high scores indicating rightist voting.[2] It is quite remarkable, for that matter, that Nieuwbeerta codes new-leftist parties as non-left parties. Given massive support for those parties from the middle class (Hoffman-Martinot 1991, Inglehart 1997: 273-288), it needs no further argument that this decision produces a less dramatic decline of the relationship between class and voting than has actually occurred.

\section{Results}

Before testing our two hypotheses, we demonstrate that EGP class, education, and income are related in ways that make EGP class too ambiguous a variable in the study of class voting. We apply multilevel regression analysis, conceiving of country, year, and respondent as three different levels of analysis.

[INSERT TABLE 2: Income explained from EGP-class and education (multilevel regression analysis, entries are regression coefficients and standard Errors, maximum likelihood estimation, $\mathrm{N}=93,567$ respondents and 15 countries, 1956-1990). ABOUT HERE]

Table 2 points out that substantial income differences exist between the seven EGP classes (Model 1). The class of higher professionals has the highest average income and the classes of skilled, semiskilled, and unskilled manual workers the lowest. The classes also differ strongly with respect to education, however, and this accounts for a substantial part of those income differences (Model 2). The seven classes differ strongly with respect to both income and education, in short, and this makes EGP class too ambiguous a variable for the study of class voting. Whereas income and education both drive class voting, as we have argued above, it is after all education alone that constitutes the driving force behind crosscutting cultural voting. 
[INSERT TABLE 3: Rightist voting explained by social class (multilevel regression analysis, entries are regression coefficients and standard errors, maximum likelihood estimation, $\mathrm{N}=93,567$ respondents and 15 countries, 1956-1990). ABOUT HERE]

Using rightist voting as the dependent variable and six EGP class dummies as the independent ones, we next turn to the relationship between EGP class and voting behavior and the way this relationship has changed in the postwar era. It is evident that the skilled, semi-skilled and unskilled workers vote for leftist parties more often than the middle class (Table 3, Model 1) and it is also clear that those traditional alignments have weakened across time (Model 2). There is nothing surprising about this finding, of course, because it has previously been published by Nieuwbeerta (1995, 1996, 2001, Nieuwbeerta and De Graaf 1999), based on an analysis of the same data.

This decline of the relationship between EGP class and voting behavior cannot be interpreted as indicating a decline of class voting just like that, however, as Table 4 points out.

[INSERT TABLE 4: Rightist voting explained by income and education (multilevel regression analysis, entries are regression coefficients and standard errors, maximum likelihood estimation, $\mathrm{N}=93,567$ respondents and 15 countries, 1956-1990). ABOUT HERE]

Although both those with high incomes and those with high levels of education are more inclined to vote for rightist parties, both of those relationships have changed across time, albeit in radically different directions. The significant cross-level interactions of education and income with year (Models 2 and 3) point out that those with low levels of education have come to vote more rightist, while those with low incomes have come to vote more leftist across the years. This is obviously not what one would expect if those two variables were two of a kind. Indeed, the former development can be interpreted as an increase of cultural voting and the latter as an increase of class voting, as we have explained above. This brings us to our principal question: has the decline of the relationship between EGP class and voting behavior indeed been caused by this increase of cultural voting?

[INSERT TABLE 5: Rightist voting explained by social class, income and education (multilevel regression analysis, entries are regression coefficients and standard errors, maximum likelihood estimation, $\mathrm{N}=93,567$ respondents and 15 countries, 1956-1990). ABOUT HERE]

Obviously, the increasing tendency of the working class to vote for rightist parties cannot be explained from the increase of class voting, i.e., the increasing tendency of those with low incomes to vote for parties on the left (Table 5, Model 2). As expected, however, the increase of cultural voting, 
i.e., the increased tendency of those with low levels of education to vote for rightist parties, accounts for most of the shift of the working class towards rightist parties (Model 3). Although the traditional class alignments have clearly weakened in the postwar era, in short, this has not been caused by a decline of class voting, but by an increase of crosscutting cultural voting.

\section{$\underline{5 . \text { Conclusion and Debate }}$}

What Stonecash has demonstrated for the United States applies more generally: class voting has not declined during the postwar era, but has even become stronger. The suggestion to the contrary has been informed by studies of the development of the bivariate relationship between occupation-based class categories (especially the EGP class schema) and voting behavior. As it happens, this type of class measure inevitably and wrongly mixes up class voting, driven by class-based economic interests, and reverse cultural voting, driven by a cultural dynamics that is instead rooted in educational differences. It as such precludes valid conclusions as to whether or not the decline of the familiar alignments denotes a decline of class voting or an increase of cultural voting.

Our findings, relying on income to indicate class more validly, and acknowledging the double role of education in driving class voting as well as reverse cultural voting, leave little to the imagination. The gradual erosion of the pattern of a leftist-voting working class and a rightist-voting middle class has been caused by an increase of crosscutting cultural voting, driven by a cultural dynamics that is rooted in educational differences. Class voting, measured more validly by using income categories, has not declined, but has in fact become even stronger in the postwar era.

The intellectual consensus that has emerged since Clark and Lipset sparked the 'Death of Class Debate' in the beginning of the 1990s does not hold that class is actually dead, to be sure, but rather that it is dying a slow - and perhaps painful - death. Our findings necessitate a critical reassessment of this consensus. Like those of Stonecash (2000) for the United States, they point out that there is nothing "dead" or "dying" about class, after all. We feel it is more apt to say that class has been buried alive under the increasing weight of cultural voting, systematically misinterpreted as a decline of class voting due to an invalid measurement practice that has become an intellectual routine since Alford's pioneering work in the 1960s. As a lamentable consequence, poor old class now suffers its undeserved and horrid fate, "with thoughts of the air and grass above, with memory of dear friends who would fly to save us if but informed of our fate, and with consciousness that of this fate they can never be informed" (Poe 1844). Disentangling class voting and cultural voting more carefully in future empirical research is necessary to save class from this "most terrific of the ghastly extremes of agony" (Ibid.). 
$\underline{\text { Notes }}$

1. Following Hout et al.'s (1993) critique of the analysis by Clark and Lipset (1991), Nieuwbeerta uses more fine-grained class distinctions than the conventional manual-nonmanual dichotomy and relies on log-oddsratios, so as to arrive at a measure of relative rather than absolute class voting. This methodological revision of the Alford index leaves it theoretically intact, however, because the resulting "kappa index" still boils down to the idea that the degree to which class drives the vote can be measured as the strength of the relationship between class and voting. It is quite telling, indeed, that Nieuwbeerta's own research points out that his methodological revision of Alford's index produces basically similar findings as the original version: "The main finding is that the various measures of class voting (yield) the same conclusions with respect to the ranking of the countries according to their levels of class voting and according to the speed of declines in class voting" (Nieuwbeerta 1996: 370).

2. Our departure from Nieuwbeerta's operationalization, and especially our decision to code the political parties according to their constituencies' left-right self-placement, causes a substantial increase of the number of missing values: 33 of the 113 original datasets are excluded, causing Sweden (with three datasets) to disappear from our analysis altogether.

\section{$\underline{\text { References }}$}

Achterberg, Peter. 2006. "Class Voting and the New Political Culture: Economic, Cultural and Environmental Voting in Late-Modern Countries.” International Sociology 21(2):237-261.

Achterberg, Peter, and Dick Houtman. 2006. “Why Do So Many People Vote 'Unnaturally’? A Cultural Explanation for Voting Behaviour." European Journal for Political Research 45(1):75-92.

Adorno, Theodor W., Else Frenkel-Brunswik, Daniel J. Levinson, and R. Nevitt Sandford. 1950. The Authoritarian Personality. Harper and Brothers.

Alford, Robert R. 1967. "Class Voting in the Anglo-American Political Systems." Pp. 67-93 in Party Systems and Voter Alignments: Cross-National Perspectives, edited by Seymour Martin Lipset, and Stein Rokkan. Free Press.

Brooks, Clem, Paul Nieuwbeerta, and Jeff Manza. 2004. "Cleavage-Based Voting Behavior in CrossNational Perspective: Evidence From Six Postwar Democracies." Social Science Research (in press). 
Clark, Terry Nichols 2001. "What Have We Learned in a Decade on Class and Party Politics?" Pp. 639 in The Breakdown of Class Politics: A Debate on Post-Industrial Stratification, edited by Terry Nichols Clark and Seymour Martin Lipset. Westview Press.

Clark, Terry Nichols, and Seymour Martin Lipset. 1991. “Are Social Classes Dying?” International Sociology 6(4):397-410.

— (eds). 2001. The Breakdown of Class Politics: A Debate on Post-Industrial Stratification. Westview Press.

De Witte, Hans, and Jaak Billiet. 1999. "Economic and Cultural Conservatism in Flanders: In Search of Concepts, Determinants and Impact on Voting Behaviour." Pp. 91-120 in Ideology in the Low Countries: Trends, Models and Lacunae, edited by Hans de Witte, and Peer Scheepers. Van Gorcum.

Dekker, Paul, and Peter Ester. 1987. "Working-Class Authoritarianism: A Re-Examination of the Lipset Thesis." European Journal of Political Research 15(4):395-415.

Duncan, Otis D. 1961. “A Socioeconomic Index for all Occupations.” Pp. 109-138 in Occupations and Social Status, edited by Albert J. Reiss, Jr. Free Press.

Erikson, Robert. 1984. "Social Class of Men, Women and Families." Sociology 18(4):500-514.

Erikson, Robert, and John H. Goldthorpe. 1992. The Constant Flux: A Study of Class Mobility in Industrial Societies. Clarendon.

Erikson, Robert, John H. Goldthorpe, and Lucienne Portocarero. 1979. "Intergenerational Class Mobility in Three Western European Countries.” British Journal of Sociology 30(3):415-441.

Evans, Geoffrey (ed.). 1999. The End of Class Politics? Class Voting in Comparative Context. Oxford University Press.

—. 2000. "The Continued Significance of Class Voting." Annual Review of Political Science 3(1):401-417.

Evans, Geoffrey, Anthony Heath, and Clive Payne. 1999. “Class: Labour as a Catch-All Party?” Pp. 87-101 in Critical Elections. British Parties and Voters in Long-Term Perspective, edited by Geoffrey Evans, and Pippa Norris. Sage.

Fleishman, John A. 1988. "Attitude Organization in the General Public: Evidence for a Bidimensional Structure." Social Forces 67(1):159-184.

Goldthorpe, John H. 1980. Social Mobility and Class Structure in Modern Britain. Clarendon.

—. 2001. "Class and Politics in Advanced Industrial Societies." Pp. 105-120 in The Breakdown of Class Politics: A Debate on Post-Industrial Stratification, edited by Terry Nichols Clark, and Seymour Martin Lipset. Westview Press.

Goldthorpe, John H., and Gordon Marshall. 1992. "The Promising Future of Class Analysis: A Response to Recent Critiques.” Sociology 26(3):381-400. 
Grabb, Edward G. 1979. "Working-Class Authoritarianism and Tolerance of Outgroups: A

Reassessment." Public Opinion Quarterly 43(1):36-47.

—. 1980. "Marxist Categories and Theories of Class: The Case of Working Class Authoritarianism." Pacific Sociological Review 23(4):359-376.

Heath, Anthony F., Geoffrey Evans, and Jean Martin. 1994. "The Measurement of Core Beliefs and Values: The Development of Balanced Socialist/Laissez Faire and Libertarian/Authoritarian Scales.” British Journal of Political Science 24(1):115-132.

Heath, Anthony F., Michael Yang, and Harvey Goldstein. 1996. "Multilevel Analysis of the Changing Relationship Between Class and Party in Britain 1964-1992.” Quality and Quantity:

European Journal for Methodology 30(4):389-404.

Hechter, Michael. 2004. "From Class to Culture.” American Journal of Sociology 110(2):400-45.

Hoffman-Martinot, Vincent. 1991. "Grüne and Verts: Two Faces of European Ecologism.” West European Politics 14(1):70-95.

Hout, Mike, Clem Brooks, and Jeff Manza. 1993. "The Persistence of Classes in Post-Industrial Societies.” International Sociology 8(3):259-277.

Houtman, Dick. 2001. "Class, Culture, and Conservatism: Reassessing Education as a Variable in Political Sociology." Pp. 161-195 in The Breakdown of Class Politics: A Debate on Post-Industrial Stratification, edited by Terry Nichols Clark, and Seymour Martin Lipset. Johns Hopkins University Press.

Houtman, Dick. 2003. Class and Politics in Contemporary Social Science: 'Marxism Lite' and Its Blind Spot for Culture. Aldine de Gruyter.

Inglehart, Ronald. 1977. The Silent Revolution: Changing Values and Political Styles among Western Publics. Princeton University Press.

- 1997. Modernization and Postmodernization: Cultural, Economic, and Political Change in 43 Societies. Princeton University Press.

Ishida, Hiroshi, and Walter Muller. 1995. "Class Origin, Class Destination, and Education: A CrossNational Study of Ten Industrial Nations.” American Journal of Sociology 101(1):145-194.

Kohn, Melvin. 1977. Class and Conformity: A Study in Values. University of Chicago Press. Layman, Geoffrey C. 2001. The Great Divide: Religious and Cultural Conflict in American Party Politics. Columbia University Press.

Lipset, Seymour Martin 1959. "Democracy and Working-Class Authoritarianism.” American Sociological Review 24(4):482-501.

- 1981. Political Man: The Social Bases of Politics (Expanded and Updated Edition). Johns Hopkins University Press. 
Manza, Jeff, Michael Hout, and Clem Brooks. 1995. "Class Voting in Capitalist Democracies Since World War II: Dealignment, Realignment, or Trendless Fluctuation?" Annual Review of Sociology 21:137-162.

Marshall, Gordon, Howard Newby, David Rose, and Carolyn Vogler. 1988. Social Class in Modern Britain. Hutchinson.

Middendorp, Cees P. 1991. Ideology in Dutch Politics: The Democratic System Reconsidered, 19701985. Van Gorcum.

Nieuwbeerta, Paul. 1995. The Democratic Class Struggle in Twenty Countries, 1945-1990. Thesis Publishers.

—. 1996. "The Democratic Class Struggle in Postwar Societies: Class Voting in Twenty Countries, 1945-1990.” Acta Sociologica 39(4):345-383.

—. 2001. "The Democratic Class Struggle in Postwar Societies: Traditional Class Voting in Twenty Countries, 1945-1990." Pp. 121-136 in The Breakdown of Class Politics: A Debate on PostIndustrial Stratification, edited by Terry Nichols Clark, and Seymour Martin Lipset. Westview Press.

Nieuwbeerta, Paul, and Nan Dirk de Graaf. 1999. “Traditional Class Voting in Twenty Postwar Societies" Pp. 23-58 in The End of Class Politics? Class Voting in Comparative Perspective, edited by Geoffrey Evans. Oxford University Press.

Nieuwbeerta, Paul, and Harry Ganzeboom. 1996. "International Social Mobility and Politics File: Documentation of an Integrated Dataset of 113 National Surveys Held in 16 countries, 19561991.” Codebook Steinmetz Archive.

Nieuwbeerta, Paul, and Wout C. Ultee. 1999. "Class Voting in Western Industrialized Countries, 1945-1990: Systematizing and Testing Explanations.” European Journal of Political Research 35(1):123-160.

Pakulski, Jan, and Malcom Waters. 1996. The Death of Class. Sage.

Poe, Edgar Allan. 1990[1844]. “The Premature Burial.” Pp. 432-441 in: Edgar Allan Poe: Selected Works (Deluxe Edition), Gramercy.

Scheepers, Peer, Manfred te Grotenhuis, and Astrid Bosch. 1999. "Trends in Conservatism in the Netherlands, 1970-1992: Effects of Individual and Contextual Characteristics." Pp. 25-49 in Ideology in the Low Countries: Trends, Models and Lacunae, edited by Hans de Witte, and Peer Scheepers. Van Gorcum.

Stonecash, Jeffrey M. 2000. Class and Party in American Politics. Westview Press.

Van de Werfhorst, Herman G., and Nan Dirk De Graaf. 2004. "The Sources of Political Orientations in Post-Industrial Society: Social Class and Education Revisited." British Journal of Sociology 55(2):211-236. 
Weakliem, David L., and Anthony Heath. 1999. "The Secret Life of Class Voting: Britain, France and the United States Since the 1930s." Pp. 97-136 in The End of Class Politics? Class Voting in Comparative Context, edited by Geoffrey Evans. Oxford University Press.

Wright, Erik Olin. 1979. Class Structure and Income Determination. Academic Press.

-. 1985. Classes. Verso. 
Class Is Not Dead - It Has Been Buried Alive

Class Voting and Cultural Voting in Postwar Western Societies (1956-1990)

[Tables and figures]

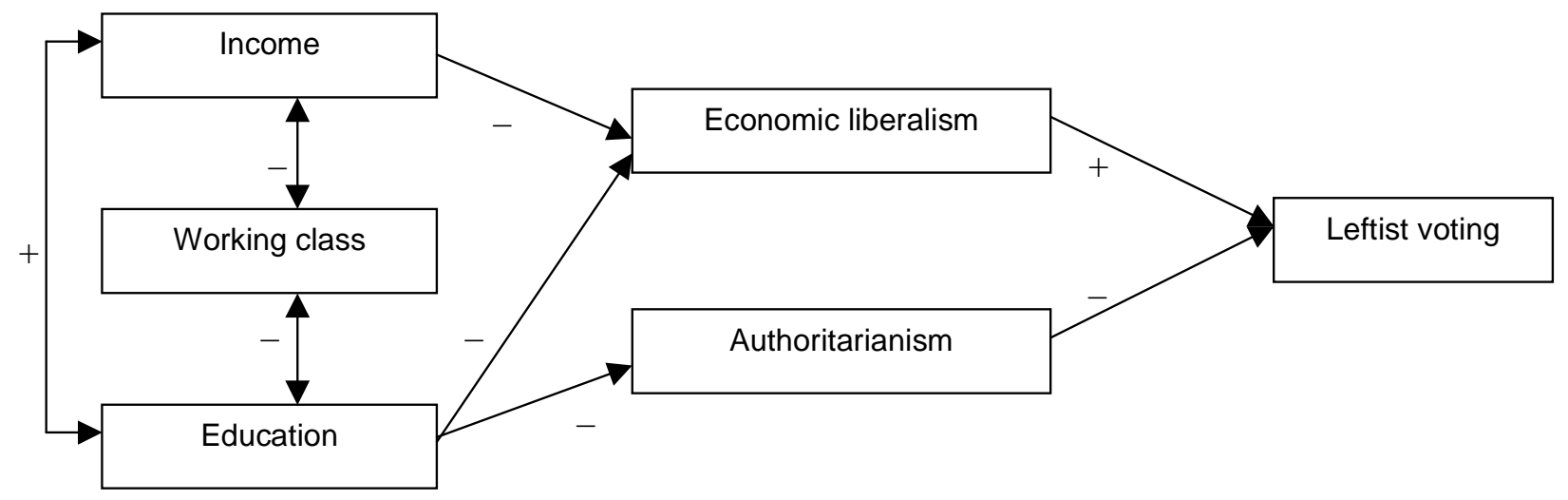

Figure 1: Class Voting Distinguished from Cultural Voting. 
Table 1: Number of data files for each of the combinations of country and period (1956-1990, $\underline{\mathrm{N}=80) \text {. }}$

\begin{tabular}{lccccr}
\hline Country & $1956-1970$ & $1971-1980$ & $1981-1990$ & Total & Period \\
\hline Australia & 1 & - & 3 & 4 & $1985-1987$ \\
Austria & - & 1 & 3 & 4 & $1974-1989$ \\
Belgium & - & 1 & - & 1 & 1975 \\
Canada & - & - & 1 & 1 & 1984 \\
Denmark & - & 1 & - & 1 & 1972 \\
Finland & - & 2 & - & 2 & $1972-1975$ \\
France & - & 1 & - & 1 & 1978 \\
Germany & 1 & 2 & 6 & 9 & $1969-1990$ \\
Great Britain & - & 2 & 6 & 8 & $1974-1990$ \\
Ireland & - & - & 1 & 1 & 1990 \\
Italy & 1 & 1 & - & 2 & $1968-1975$ \\
The Netherlands & 1 & 6 & 7 & 14 & $1970-1990$ \\
Norway & 1 & 2 & 4 & 7 & $1965-1990$ \\
Switzerland & - & 1 & - & 1 & 1976 \\
United States & 7 & 8 & 9 & 24 & $1956-1990$ \\
\hline Total & 12 & 28 & 40 & 80 & $1956-1990$ \\
\hline
\end{tabular}


Table 2: Income explained from EGP-class and education (multilevel regression analysis, entries are regression coefficients and standard Errors, maximum likelihood estimation, $\mathrm{N}=93,567$ respondents and 15 countries, 1956-1990).

\begin{tabular}{|c|c|c|c|c|c|c|}
\hline \multirow{2}{*}{$\begin{array}{l}\text { Independents } \\
\text { Constant }\end{array}$} & \multicolumn{2}{|c|}{ Null model } & \multicolumn{2}{|c|}{ Model 1} & \multicolumn{2}{|c|}{ Model 2} \\
\hline & $3.146 * * *$ & $(.297)$ & $3.146 * * *$ & $(.297)$ & $3.146 * * *$ & $(.297)$ \\
\hline Higher professionals (=ref.) & & & 0 & & 0 & \\
\hline Lower professionals & & & $-.222 * * *$ & $(.011)$ & $-.206 * * *$ & $(.011)$ \\
\hline Non-manual workers & & & $-.568 * * *$ & $(.012)$ & $-.380 * * *$ & $(.012)$ \\
\hline Petty bourgeoisie & & & $-.427 * * *$ & $(.009)$ & $-.242 * * *$ & $(.010)$ \\
\hline Higher working class & & & $-.179 * * *$ & $(.008)$ & $-.089 * * *$ & $(.008)$ \\
\hline Skilled workers & & & $-.612 * * *$ & $(.011)$ & $-.368 * * *$ & $(.011)$ \\
\hline Semi and unskilled workers & & & $-.867 * * *$ & $(.011)$ & $-.545 * * *$ & $(.012)$ \\
\hline Education & & & & & $.587 * * *$ & $(.008)$ \\
\hline Variance country level & .772 & $(.457)$ & .771 & $(.456)$ & .771 & $(.456)$ \\
\hline Variance year level & $1.429 * * *$ & $(.248)$ & $1.430 * * *$ & $(.248)$ & $1.430 * * *$ & $(.248)$ \\
\hline Variance individual level & $5.405 * * *$ & $(.025)$ & $4.948 * * *$ & $(.023)$ & $4.695 * * *$ & $(.022)$ \\
\hline Deviance & 423871.7 & & 415616.9 & & 410698.2 & \\
\hline
\end{tabular}

$* \mathrm{p}<.05 ; * * \mathrm{p}<.01 ; * * * \mathrm{p}<.001$ 

Table 3: Rightist voting explained by social class (multilevel regression analysis, entries are regression coefficients and standard errors, maximum likelihood estimation, $\mathrm{N}=93,567$

respondents and 15 countries, 1956-1990).

\begin{tabular}{|c|c|c|c|c|}
\hline & Model 1 & & Model 2 & \\
\hline Constant & $4.796 * * *$ & $(.191)$ & $4.796 * * *$ & $(.191)$ \\
\hline \multicolumn{5}{|l|}{ Fixed effects } \\
\hline Higher professionals (ref.) & 0 & & 0 & \\
\hline Lower professionals & $-.086 * * *$ & $(.018)$ & $-.090 * * *$ & $(.018)$ \\
\hline Non-manual workers & $-.139 * * *$ & $(.022)$ & $-.141 * * *$ & $(.022)$ \\
\hline Petty bourgeoisie & .058 & $(.029)$ & .055 & $(.029)$ \\
\hline Higher working class & $-.083 * * *$ & $(.023)$ & $-.084 * * *$ & $(.023)$ \\
\hline Skilled workers & $-.313 * * *$ & $(.052)$ & $-.313 * * *$ & $(.052)$ \\
\hline Semi and unskilled workers & $-.307 * * *$ & $(.057)$ & $-.308 * * *$ & $(.057)$ \\
\hline Year & .020 & $(.024)$ & .020 & $(.024)$ \\
\hline \multicolumn{5}{|l|}{ Interactions } \\
\hline Year x Higher professionals (ref.) & & & 0 & \\
\hline Year x Lower professionals & & & -.011 & $(.008)$ \\
\hline Year x Non-manual workers & & & $.019 *$ & $(.009)$ \\
\hline Year x Petty bourgeoisie & & & .013 & $(.008)$ \\
\hline Year $\mathrm{x}$ Higher working class & & & .011 & $(.008)$ \\
\hline Year x Skilled workers & & & $.037 * *$ & $(.009)$ \\
\hline Year x Semi and unskilled workers & & & $.033 * *$ & $(.010)$ \\
\hline \multicolumn{5}{|l|}{ Variance random slopes country level } \\
\hline Lower professionals & .003 & $(.002)$ & .003 & $(.002)$ \\
\hline Non-manual workers & $.005 *$ & $(.002)$ & $.005^{*}$ & $(.002)$ \\
\hline Petty bourgeoisie & $.009 *$ & $(.004)$ & $.009 *$ & $(.004)$ \\
\hline Higher working class & .005 & $(.003)$ & .005 & $(.003)$ \\
\hline Skilled workers & $.038 *$ & $(.015)$ & $.037 *$ & $(.015)$ \\
\hline Semi and unskilled workers & $.045^{*}$ & $(.018)$ & $.044 *$ & $(.017)$ \\
\hline \multicolumn{5}{|l|}{$\begin{array}{l}\text { Variance random slopes year level } \\
\text { Higher professionals (ref.) }\end{array}$} \\
\hline Lower professionals & .001 & $(.001)$ & .000 & $(.000)$ \\
\hline Non-manual workers & $.001 *$ & $(.000)$ & $.001 *$ & $(.000)$ \\
\hline Petty bourgeoisie & .001 & $(.001)$ & .001 & $(.001)$ \\
\hline Higher working class & $.002 *$ & $(.001)$ & $.002 *$ & $(.001)$ \\
\hline Skilled workers & $.002 *$ & $(.001)$ & .001 & $(.001)$ \\
\hline Semi and unskilled workers & $.002 *$ & $(.001)$ & .001 & $(.001)$ \\
\hline Variance country level & $.523 * *$ & $(.191)$ & $.523 * *$ & $(.191)$ \\
\hline Variance year level & $.040 * * *$ & $(.007)$ & $.040 * * *$ & $(.007)$ \\
\hline Variance individual level & $2.036 * * *$ & $(.009)$ & $2.036 * * *$ & $(.009)$ \\
\hline Deviance & 332794.4 & & 332746.8 & \\
\hline
\end{tabular}

$* \mathrm{p}<.05 ; * * \mathrm{p}<.01 ; * * * \mathrm{p}<.001$ 
Table 4: Rightist voting explained by income and education (multilevel regression analysis, entries are regression coefficients and standard errors, maximum likelihood estimation, $\mathrm{N}=93,567$ respondents and 15 countries, 1956-1990).

\begin{tabular}{|c|c|c|c|c|c|c|}
\hline & Model 1 & & Model 2 & & Model 3 & \\
\hline Constant & $4.796 * * *$ & $(.191)$ & $4.796 * * *$ & $(.191)$ & $4.796 * * *$ & $(.191)$ \\
\hline \multicolumn{7}{|l|}{ Fixed effects } \\
\hline Income & $.099 * *$ & $(.027)$ & $.098 * *$ & $(.027)$ & $.101 * *$ & $(.028)$ \\
\hline Education & $.104 *$ & $(.048)$ & $.100 *$ & $(.048)$ & $.099 *$ & $(.046)$ \\
\hline Year & .020 & $(.024)$ & .020 & $(.024)$ & .020 & $(.024)$ \\
\hline \multicolumn{7}{|l|}{ Interactions } \\
\hline Education $\mathrm{x}$ year & & & $-.037 * *$ & $(.009)$ & $-.040 * *$ & $(.009)$ \\
\hline Income $\mathrm{x}$ year & & & & & $.024 *$ & $(.010)$ \\
\hline \multicolumn{7}{|c|}{ Variance random slopes country level } \\
\hline Income & .007 & $(.004)$ & .007 & $(.004)$ & .007 & $(.004)$ \\
\hline Education & $.031 *$ & $(.013)$ & $.028 *$ & $(.011)$ & $.028 *$ & $(.011)$ \\
\hline \multicolumn{7}{|c|}{ Variance random slopes year level } \\
\hline Income & $.006 * * *$ & $(.001)$ & $.006 * * *$ & $(.001)$ & $.005 * * *$ & $(.001)$ \\
\hline Education & $.004 * *$ & $(.001)$ & $.003 * *$ & $(.001)$ & $.003 * *$ & $(.001)$ \\
\hline Variance country level & $.523 * *$ & $(.191)$ & $.523 * *$ & $(.191)$ & $.523 * *$ & $(.191)$ \\
\hline Variance year level & $.040 * * *$ & $(.007)$ & $.040 * * *$ & $(.007)$ & $.040 * * *$ & $(.007)$ \\
\hline Variance individual level & $2.114 * * *$ & $(.009)$ & $2.114 * * *$ & $(.009)$ & $2.114 * * *$ & $(.009)$ \\
\hline Deviance & 131.1 & & 114.1 & & 108.5 & \\
\hline
\end{tabular}

$* \mathrm{p}<.05 ; * * \mathrm{p}<.01 ; * * * \mathrm{p}<.001$ 
Table 5: Rightist voting explained by social class, income and education (multilevel regression analysis, entries are regression coefficients and standard errors, maximum likelihood estimation, $\mathrm{N}=93,567$ respondents and 15 countries, 1956-1990).

\begin{tabular}{|c|c|c|c|c|c|c|}
\hline & Model 1 & & Model 2 & & Model 3 & \\
\hline Constant & $4.796 * * *$ & $(.191)$ & $4.796 * * *$ & $(.191)$ & $4.796 * * *$ & $(.191)$ \\
\hline \multicolumn{7}{|l|}{ Fixed effects } \\
\hline Higher professionals (ref.) & 0 & & 0 & & 0 & \\
\hline Lower professionals & $-.077 * * *$ & $(.018)$ & $-.072 * * *$ & $(.018)$ & $-.072 * * *$ & $(.018)$ \\
\hline Non-manual workers & $-.118 * * *$ & $(.024)$ & $-.101 * * *$ & $(.022)$ & $-.101 * * *$ & $(.022)$ \\
\hline Petty bourgeoisie & $.079 * *$ & $(.030)$ & $.108 * *$ & $(.029)$ & $.108 * *$ & $(.029)$ \\
\hline Higher working class & $-.076 * *$ & $(.023)$ & $-.071 * *$ & $(.023)$ & $-.071 * *$ & $(.023)$ \\
\hline Skilled workers & $-.284 * * *$ & $(.053)$ & $-.256 * * *$ & $(.052)$ & $-.256 * * *$ & $(.052)$ \\
\hline Semi and unskilled workers & $-.272 * * *$ & $(.058)$ & $-.244 * * *$ & $(.057)$ & $-.244 * * *$ & $(.057)$ \\
\hline Income & $.097 * *$ & $(.005)$ & $.086 * *$ & $(.019)$ & $.086 * *$ & $(.019)$ \\
\hline Education & -.005 & $(.006)$ & .020 & $(.038)$ & .020 & $(.038)$ \\
\hline Year & .020 & $(.024)$ & .020 & $(.024)$ & .020 & $(.024)$ \\
\hline \multicolumn{7}{|l|}{ Interactions } \\
\hline Year x Higher professionals (ref.) & 0 & 0 & 0 & 0 & 0 & 0 \\
\hline Year x Lower professionals & -.010 & $(.008)$ & -.011 & $(.008)$ & -.012 & $(.008)$ \\
\hline Year x Non-manual workers & $.019 *$ & $(.008)$ & .016 & $(.009)$ & .012 & $(.009)$ \\
\hline Year x Petty bourgeoisie & .007 & $(.008)$ & .003 & $(.009)$ & -.002 & $(.009)$ \\
\hline Year x Higher working class & .011 & $(.008)$ & .008 & $(.007)$ & .006 & $(.007)$ \\
\hline Year x Skilled workers & $.034 * *$ & $(.009)$ & $.030 * *$ & $(.009)$ & $.024 * *$ & $(.009)$ \\
\hline Year x Semi and unskilled workers & $.019 * *$ & $(.010)$ & $.025 * *$ & $(.010)$ & .017 & $(.010)$ \\
\hline Year x Income & & & $.025 * *$ & $(.009)$ & $.029 * *$ & $(.009)$ \\
\hline Year x Education & & & & & $-.038 * *$ & $(.009)$ \\
\hline \multicolumn{7}{|l|}{$\begin{array}{l}\text { Variance random slopes country level } \\
\text { Higher professionals (ref.) }\end{array}$} \\
\hline Lower professionals & .003 & $(.002)$ & $.002 *$ & $(.001)$ & $.002 *$ & $(.001)$ \\
\hline
\end{tabular}




\begin{tabular}{|c|c|c|c|c|c|c|}
\hline Non-manual workers & .005 & $(.003)$ & .001 & $(.001)$ & .001 & $(.001)$ \\
\hline Petty bourgeoisie & $.010 *$ & $(.005)$ & $.014 *$ & $(.006)$ & $.014 *$ & $(.006)$ \\
\hline Higher working class & .005 & $(.003)$ & $.004 *$ & $(.002)$ & $.004 *$ & $(.002)$ \\
\hline Skilled workers & $.038 * *$ & $(.015)$ & $.019 *$ & $(.008)$ & $.019 *$ & $(.008)$ \\
\hline Semi and unskilled workers & $.046 *$ & $(.018)$ & $.023 *$ & $(.009)$ & $.023 *$ & $(.009)$ \\
\hline Income & .003 & $(.002)$ & .003 & $(.002)$ & .003 & $(.002)$ \\
\hline Education & $.021 *$ & $(.009)$ & $.018 *$ & $(.008)$ & $.018 *$ & $(.008)$ \\
\hline \multicolumn{7}{|c|}{$\begin{array}{l}\text { Variance random slopes year level } \\
\text { Higher professionals (ref.) }\end{array}$} \\
\hline Lower professionals & .000 & $(.000)$ & .000 & $(.000)$ & .000 & $(.000)$ \\
\hline Non-manual workers & .000 & $(.000)$ & .000 & $(.000)$ & .000 & $(.000)$ \\
\hline Petty bourgeoisie & .001 & $(.001)$ & .001 & $(.001)$ & .001 & $(.001)$ \\
\hline Higher working class & .002 & $(.001)$ & .001 & $(.001)$ & .001 & $(.001)$ \\
\hline Skilled workers & $.001 *$ & $(.000)$ & $.001 *$ & $(.000)$ & $.001 *$ & $(.000)$ \\
\hline Semi and unskilled workers & .001 & $(.001)$ & $.001 *$ & $(.000)$ & .001 & $(.001)$ \\
\hline Income & $.003 * *$ & $(.001)$ & $.003 * *$ & $(.001)$ & $.003 * *$ & $(.001)$ \\
\hline Education & $.004 * *$ & $(.001)$ & $.004 * *$ & $(.001)$ & $.003 * *$ & $(.001)$ \\
\hline Variance country level & $.523 * *$ & $(.191)$ & $.523 * *$ & $(.191)$ & $.523 * *$ & $(.191)$ \\
\hline Variance year level & $.040 * * *$ & $(.007)$ & $.040 * * *$ & $(.007)$ & $.040 * * *$ & $(.007)$ \\
\hline Variance individual level & $2.028 * * *$ & $(.009)$ & $2.014 * * *$ & $(.009)$ & $2.014 * * *$ & $(.009)$ \\
\hline Deviance & 332375.6 & & 331881.0 & & 881.0 & \\
\hline
\end{tabular}

$* \mathrm{p}<.05 ; * * \mathrm{p}<.01 ; * * * \mathrm{p}<.001$ 